\title{
Pengaruh Perencanaan Anggaran dan Pengendalian Intern terhadap Akuntabilitas Publik pada Pemerintah Daerah Provinsi Riau
}

\author{
Neli Agustin \\ Program Studi Akuntansi Keuangan Publik, Politeknik Negeri Bengkalis \\ Email: neliagustin12071997@gmail.com
}

\begin{abstract}
This study aims to empirically examine the effect of budget planning and internal control on public accountability in the Riau Provincial Government. This study uses quantitative methods because it emphasizes the method of data analysis with statistical procedures. The type of data used in this study is primary data. Primary data obtained from the distribution of questionnaires distributed by researchers to respondents contained in SKPD of the Regional Government of Riau Province. The research sample is SKPD employees who work in the planning department as well as employees who are the internal audit team at the SKPD in the Riau Provincial Government. The statistical method uses Multiple Linear Regression Analysis. The results of this study indicate that budget planning and internal control have a positive and significant effect on public accountability in Riau province.
\end{abstract}

Keywords: Employees, Budget Planning, Internal Control, Public Accountability

\begin{abstract}
ABSTRAK
Penelitian ini bertujuan untuk menguji secara empiris pengaruh perencanaan anggaran dan pengendalian intern terhadap akuntabilitas publik pada Pemerintah Daerah Provinsi Riau. Penelitian ini menggunakan metode kuantitatif karena menekankan pada metode analisis data dengan prosedur statistik. Jenis data yang digunakan dalam penelitian ini adalah data primer. Data primer diperolah dari penyebaran kuesioner yang disebarkan peneliti kepada responden yang terdapat di SKPD Pemerintah Daerah Provinsi Riau. Sampel penelitian adalah pegawai SKPD yang bekerja pada bagian perencanaan serta pegawai yang menjadi tim audit internal pada SKPD di Pemerintah Daerah Provinsi Riau. Metode statistik menggunakan Analisis Regresi Linear Berganda. Hasil penelitian ini menunjukkan bahwa perencanaan anggaran dan pengendalian intern berpengaruh secara signifikan terhadap akuntabilitas publik di provinsi Riau.
\end{abstract}

Kata kunci: Pegawai, Perencanaan Anggaran, Pengendalian Intern, Akuntabilitas Publik

\section{Pendahuluan}

Latar Belakang

Akuntabilitas publik di Indonesia masih sangat lemah karena masih banyak uang negara yang diambil oleh koruptor. Hal tersebut membuat akuntabilitas pemerintah masih rendah. Sama halnya dengan kasus korupsi yang terjadi di Kabupaten Bengkalis yang saat ini marak dibicarakan di berbagai media, dan di kalangan masyarakat. Salah satunya yaitu kasus yang menjerat Bupati Bengkalis yang menggelapkan dana sebesar 5,6 Miliar. Oleh karena itu, penting untuk mewujudkan akuntabilitas publik. Salah satu caranya yaitu dengan adanya perencanaan anggaran dan pengendalian intern yang baik. Perencanaan anggaran mencakup penyusunan kebijakan umum APBD sampai dengan disusunnya rancangan APBD. Adapun tujuan dari penggunaan dana pemerintah yaitu tepat sasaran sehingga dana digunakan secara efektif dan efisien. 
Adanya pengendalian intern di pemerintah diharapkan dapat meminimalisir terjadinya kecurangan dalam organisasi khususnya yang berkaitan dengan keuangan negara. Pengendalian intern di pemerintah masih banyak kelemahan, salah satunya yaitu hasil pemeriksaan LKPP semester I tahun 2018 oleh Badan Pemeriksa Keuangan Republik Indonesia (BPK) mengungkapkan 15.77 permasalahan. Permasalahan tersebut meliputi kelemahan sistem pengendalian intern (SPI) senilai 11,55 triliun, ketidak patuhan terhadap ketentuan peraturan perundang-undangan senilai Rp10,06 triliun, serta permasalahan ketidak hematan, ketidak efisienan, dan ketidak efektifan senilai Rp1,49 triliun. Ketua BPK menjelaskan bahwa permasalahan ketidak patuhan mengakibatkan kerugian senilai Rp2,34 triliun, potensi kerugian senilai Rp1,03 triliun, serta kekurangan penerimaan senilai Rp6,69 triliun. Terhadap masalah ketidak patuhan tersebut pada saat pemeriksaan, entitas yang diperiksa telah menindaklanjuti dengan menyerahkan aset atau menyetor ke kas negara/daerah/perusahaan Rp676,15 miliar (bpk.go.id. 23/05/2019).

Perencanaan anggaran dan pengendalian intern merupakan kegiatan yang paling penting dalam pengelolaan keuangan negara karena berkaitan dengan akuntabilitas kepada publik. Fenomena tersebut membuktikan bahwa masih banyak pembenahan yang harus dilakukan dalam pemerintah Daerah di Indonesia khususnya di Provinsi Riau. Berdasarkan fenomena yang terjadi, maka penulis terdorong untuk melakukan suatu penelitian tentang bagaimana pengaruh penyusunan anggaran dan pengendalian intern terhadap Akuntabilitas Publik baik secara parsial maupun simultan pada Pemerintah Daerah Provinsi Riau.

\section{Tinjauan Pustaka}

\section{Peneliti Terdahulu}

Penelitian terdahulu ini menjadi salah satu acuan penulis dalam melakukan penelitian sehingga penulis dapat memperkaya teori yang digunakan dalam mengkaji penelitian yang dilakukan.

Andyrwanto (2016), melakukan penelitian yang berjudul pengaruh perencanaan anggaran dan pengendalian intern terhadap akuntabilitas keuangan daerah dengan realisasi anggaran sebagai variabel intervening. Hasil dari penelitian ini adalah Perencanaan anggaran tidak berpengaruh terhadap akuntabilitas publik. Sedangkan pengendalian intern mempunyai pengaruh yang signifikan terhadap akuntabilitas publik.

Rakhmini juwita (2016), melakuan penelitian dengan judul Pengaruh perencanaan anggaran dan pengendalian intern terhadap akuntabilitas publik pada pemerintah daerah provinsi banten. Hasil dari penelitian ini Perencanaan anggaran dan pengendalian intern berpengaruh signifikan terhadap akuntabilitas publik.

\section{Perencanaan Anggaran \\ Pengertian Anggaran}

Conyers dan Hills (1994), mendefenisikan Perencanaan Sebagai" Suatu proses yang berkesinambungan yang mencakup keputusan-keputusan atau pilihan-pilihan atas berbagai alternatif penggunaan sumber daya untuk mencapai tujuan-tujuan tertentu di masa yang akan datang. 


\section{Fungsi Anggaran}

Anggaran dalam manajemen organisasi sektor publik memiliki beberapa fungsi.

Menurut Nordiawan (2008), fungsi anggaran diantaranya yaitu:

a) Anggaran sebagai Alat Perencanaan, dengan adanya anggaran organisasi tahu apa yang harus dilakukan dan ke arah mana kebijakan yang akan dibuat.

b) Anggaran sebagai Alat Pengendalian, dengan adanya anggaran organisasi dapat menghindari adanya pengeluaran yang terlalu besar (overspending) atau adanya penggunaan dana yang tidak semestinya (misspending).

c) Anggaran sebagai Alat Kebijakan, melalui anggaran organisasi dapat menentukan arah atas kebijakan tertentu.

d) Anggaran sebagai Alat Politik dalam organisasi, melalui anggaran dapat dilihat komitmen pengelola dalam melaksanakan program-program yang telah dijanjikan.

e) Anggaran sebagai Alat Koordinasi dan Komunikasi, melalui dokumen anggaran yang komprehensif sebuah bagian atau unit kerja atau departemen yang merupakan sub organisasi dapat mengetahui apa yang harus dilakukan dan juga apa yang akan dilakukan oleh bagian atau unit kerja lainnya.

f) Anggaran sebagai alat Penilaian Kinerja, anggaran adalah suatu ukuran yang bisa menjadi patokan apakah suatu bagian atau unit kerja telah memenuhi target baik berupa terlaksananya aktivitas maupun terpenuhinya efisiensi biaya.

g) Anggaran sebagai alat Motivasi, anggaran dapat digunakan sebagai alat komunikasi dengan menjadikan nilai-nilai nominal yang tercantum sebagai target pencapaian.

\section{Pengendalian Intern}

\section{Pengertian Pengendalian Internal}

Menurut Hery (2011), sistem pengendalian intern terdiri atas kebijakan dan prosedur yang dirancang untuk memberikan kepastian yang layak bagi manajemen, bahwa perusahaan telah mencapai tujuan dan sasarannya. Manajemen memiliki tiga tujuan umum dalam merancang sistem pengendalian intern yang efektif, yaitu keandalan pelaporan keuangan, efisiensi, dan efektivitas operasi serta ketaatan pada hukum dan peraturan. Pengertian SPI menurut Peraturan Pemerintah (PP) nomor 8 tahun 2006 tentang pelaporan keuangan dan kinerja instansi pemerintah, Sistem Pengendalian Intern adalah suatu proses yang dipengaruhi oleh manajemen yang diciptakan untuk memberikan keyakinan yang memadai dalam pencapaian efektivitas, efisiensi, ketaatan terhadap peraturan perundang-undangan yang berlaku, dan keandalan penyajian laporan keuangan Pemerintah.

\section{Akuntabilitas Publik Pengertian Akuntabilitas}

Akuntabilitas (Accountability) secara bahasa dapat diartikan sebagai Pertaggung jawaban. Akuntabilitas mengandung arti pertanggungjawaban, baik oleh orang-orang maupun badan-badan yang dipilih, atas pilihan-pilihan dan tindakan-tindakannya. Akuntabilitas diartikan sebagai kewajiban untuk memberikan pertanggungjawaban atau untuk menjawab dan menjelaskan kinerja dan tindakan seseorang/badan hukum/pimpinan kolektif suatu organisasi kepada pihak yang memiliki hak/berkewenangan untuk meminta keterangan atau pertanggungjawaban. Oleh karena itu, pemberlakuan undang-undang otonomi daerah harus dapat meningkatkan daya inovatif dari pemerintah daerah untuk dapat memberikan laporan pertanggungjawaban 
mengenai pengelolaan keuangan daerah dari segi efisiensi dan efektivitas kepada DPRD maupun masyarakat luas (Wahida, 2015).

\section{Manfaat Akuntabilitas}

Manfaat akuntabilitas pada dasarnya memberi perhatian pada hasil-hasil dari kegiatan pemerintahan. Hasil kegiatannya terfokus pada efektivitas, tidak sekedar kepatuhan terhadap prosedur. Bukan hanya output, tapi sampai outcome. Outcome adalah dampak suatu program atau kegiatan terhadap masyarakat. Outcome lebih tinggi nilainya daripada output, karena output hanya mengukur dari hasil tanpa mengukur dampaknya terhadap masyarakat, sedangkan outcome mengukur output dan dampak yang dihasilkan. Pengukuran outcome memiliki dua peran yaitu restopektif dan prospektif. Pera restopektif terkait dengan penilaian kinerja(Setiawan, 2012).

\section{Akuntabilitas laporan Keuangan Pemerintah}

Akuntabilitas Laporan Keuangan Pemerintah Daerah (LKPD) menjadi hal penting karena merupakan bentuk pertanggungjawaban pemerintah daerah terhadap pelaksanaan APBD. Untuk mengetahui akuntabilitas laporan keuangan pemerintah daerah perlu dilakukan pemeriksaan (diaudit). Pemeriksaan tentang akuntabilitas LKPD dilakukan BPK RI sebagai pemeriksa pengelolaan dan tanggung jawab tentang keuangan Negara sebagaimana dijelaskan dalam Undang-Undang Republik Indonesia nomor 15 tahun 2006 tentang Badan Pemeriksa Keuangan.

\section{Metode Penelitian \\ Data Penelitian}

Dalam penelitian ini menggunakan data primer. Data primer adalah data penelitian yang diperoleh secara langsung dari sumber aslinya tidak melalui perantara. Dalam hal ini data primer diperoleh dari jawaban responden terhadap kuesioner yang diajukan kepada responden. Data primer pada penelitian ini diperolah dari penyebaran kuesioner yang disebarkan peneliti kepada responden yang terdapat di SKPD di Pemerintah Daerah Provinsi Riau.

\section{Populasi}

Populasi yang akan digunakan dalam penelitian ini adalah Satuan Kerja Perangkat Daerah (SKPD) yang berada di lingkungan Instansi Pemerintahan Daerah Provinsi Riau.

\section{Sampel}

Sampel adalah bagian dari populasi yang diambil melalui cara-cara tertentu yang juga memiliki karakteristik tertentu, jelas, lengkap dan dianggap bisa mewakili populasi. Metode penentuan sampel pada penelitian ini menggunakan purposive sampling yaitu dengan mengambil sampel berdasarkan pertimbangan tertentu. Sampel yang digunakan dalam penelitian ini yaitu Dinas Kesehatan, Dinas Pekerjaan Umum, Dinas Pertanian, Dinas Kebersihan, Inspektorat Kabupaten, Bappeda, Badan Pemberdayaan Masyarakat, Kesbang, Kantor Pelayanan terpadu, Dinas Koperasi yang merupakan instansi yang terkait dengan anggaran. Kriteria sampel dalam penelitian ini yaitu pegawai yang mempunyai jabatan struktural dalam SKPD yaitu kepala Dinas, Sekretaris, Kepala Sub Bagian, Kepala Bidang dan Kepala Seksi sehingga yang menjadi responden adalah 
pegawai yang mengerti tentang proses penganggaran dan yang paham tentang Pengendalian Internal.

\section{Variabel Penelitian}

1. Variabel Independen (X)

a. Perencanaan Anggaran (X1). Untuk mengukur variabel perencanaan anggaran, maka dalam penelitian ini menggunakan aspek penyusunan rencana kerja anggaran SKPD menurut PP Nomor 58 tahun 2005.

b.

engendalian Intern (X2). Untuk mengukur variable Pengendalian Intern menggunakan teori COSO dan PP Nomor 60 tahun 2008 yaitu: (a) lingkungan pengendalian, (b) Penaksiran resiko, (c) Aktifitas Pengendalian (d) Informasi dan komunikasi (e) Pemantauan.

2. Variabel Dependen (Y)

Variabel dependen pada penelitian ini yaitu Implementasi Prinsip Akuntabilitas Publik yang diukur dengan menggunakan teori dari elwood yang terdapat dalam Renyowijoyo (2012), yang menyatakan bahwa akuntabilits publik terdiri atas: (a) Akuntabilitas Kejujuran dan Hukum, (b) Akuntabilitas Proses, (c) Akuntabilitas Program, (d) Akuntabilitas Kebijakan.

\section{Hasil dan Pembahasan}

\section{Uji Normalitas}

Pengujian normalitas data dilakukan dengan menggunakan Kolmogorov-Smirnov dengan alpha sebesar 5\%. Hasil uji normalitas data dapat dilihat pada Tabel 1.

Tabel 1

Hasil Uji Normalitas Kolmogorov-Smirnov

\begin{tabular}{|l|l|c|}
\hline \multicolumn{2}{|c|}{ Keterangan } & \multicolumn{1}{c|}{$\begin{array}{c}\text { Unstandardized } \\
\text { Residual }\end{array}$} \\
\hline $\mathrm{N}$ & Mean & 32 \\
\cline { 2 - 3 } $\begin{array}{l}\text { Normal } \\
\text { Parametersa,b }\end{array}$ & Std. Deviation & 0,000 \\
\hline \multirow{3}{*}{$\begin{array}{l}\text { Most Extreme } \\
\text { Differences }\end{array}$} & Absolute & 1,11608561 \\
\cline { 2 - 3 } & Positive & 0,123 \\
\cline { 2 - 3 } & Negative & 0,077 \\
\hline \multicolumn{2}{|l|}{ Test Statistic } & $-0,123$ \\
\hline Asymp. Sig. (2-tailed) & 0,123 \\
\hline
\end{tabular}

Berdasarkan tabel di atas dapat dilihat bahwa nilai signifikan sebesar 0.200 lebih besar 0,05. Hal ini dapat diartikan bahwa data berdistribusi normal.

\section{Uji Validitas}


Penelitian ini telah lolos uji validitas serta model penelitian juga tidak memiliki masalah asumsi klasik. Dengan menggunakan analisis regresi berganda, tabel di bawah ini menunjukkan hasil uji hipotesis.

Tabel 2

Hasil Uji Validitas

Koefisien

\begin{tabular}{|c|l|c|c|c|c|c|}
\hline \multicolumn{2}{|c|}{ Model } & \multicolumn{2}{|c|}{$\begin{array}{c}\text { Unstandardized } \\
\text { Coefficients }\end{array}$} & $\begin{array}{c}\text { Standardized } \\
\text { Coefficients }\end{array}$ & \multirow{2}{*}{ T } & \multirow{2}{*}{ Sig. } \\
\cline { 2 - 5 } \multicolumn{2}{c|}{} & B & Std. Error & Beta & & \\
\hline \multirow{2}{*}{1} & Konstan) & 2,533 & 1,736 & & 1,459 & 0,155 \\
\cline { 2 - 7 } & Perencanaan(X1) & 0,138 & 0,129 & 0,127 & 1,07 & 0,294 \\
\cline { 2 - 7 } & Pengendalian Intern(X2) & 0,663 & 0,106 & 0,746 & 6,281 & 0,000 \\
\hline
\end{tabular}

Dari tabel diatas menunjukkan bahwa persamaan regresi berganda yang diperoleh dari hasil analisis dengan mengunakan software SPSS versi 22,00. Yaitu:

$$
Y=2,533+0,138 \times 1+0,663 \times 2
$$

Dari persamaan di atas maka dapat dijelaskan bahwa perencanaan anggaran dan pengendalian intern berpengaruh secara positif dan signifikan terhadap akuntabilitas publik yang terlihat dari nilai koefisien regresi variabel perencanaan anggaran (X1) diperoleh sebesar 0.138 dengan tingkat signifikan 0,294. Sedangkan koefesien regresi variabel pengendalian internal (X2) 0.663 dengan tingkat signifikansi 0.000 . Jadi dapat dijelaskan bahwa pengaruh perencanaan anggaran dan pengendalian intern terhadap akuntabilitas publik berpengaruh secara positif yang terlihat dari koefisien regresi yang diperoleh positif. Selain pengaruh dari perencanaan anggaran dan pengendalian intern ada faktor-faktor atau variabel-variabel lain juga yang mempengaruhi akuntabilitas publik (Y) yang ditandai oleh simbol epsilon (å1). Sehingga hubungan tersebut dapat disimpulkan sebagai berikut:

a) Konstanta $(\alpha)$ sebesar 2,533 yang berarti apabila perencanaan dan pengendalian intern tidak ada perubahan maka tingkat akuntabilitas publik cenderung positif atau akan meningkat.

b) (nilai koefisien regresi X1) 0,138 perncanaan anggaran bernilai positif, hal ini dapat diartikan bahwa jika perencanaan anggran (X1) ditingkatkan sedangkan variabel lain adalah tetap (konstan) maka akuntabilitas publik akan meningkat.

c) b(nilai koefisien regresi X2) 0,663 pengendalian intern bernilai positif, hal ini dapat diartikan bahwa jika pengendalian intern (X2) meningkat sedangkan variabel lain adalah tetap (konstan) maka tingkat akuntabilitas publik akan meningkat.

\section{Pengaruh Perencanaan Anggaran Terhadap Akuntabilitas Publik}

Dari hasil pengujian hipotesis yang dilakukan pada penelitian ini, menunjukkan bahwa terdapat pengaruh signifikan antara perencanaan anggaran terhadap akuntabilitas publik. Hal tersebut berdasarkan hasil uji statistik diperoleh niali t hitung lebih kecil dari nilai t table $1.070<1.694$ sehingga $\mathrm{H} 0$ diterima dan $\mathrm{H} 1$ ditolak. 
Tabel 3

Koefisien Korelasi dan Determinasi Pengaruh X1 Terhadap Y

\begin{tabular}{l|c|c|c|c|}
\multicolumn{1}{c|}{ Model Summary } \\
\hline Model & $\mathrm{R}$ & R Square & $\begin{array}{c}\text { Adjusted R } \\
\text { Square }\end{array}$ & $\begin{array}{c}\text { Std. Error of } \\
\text { the Estimate }\end{array}$ \\
\hline 1 &, $366^{\mathrm{a}}$ &, 134 &, 105 & 2,031 \\
\hline
\end{tabular}

Berdasarkan hasil olah data pada Tabel 03, nilai koefesien korelasi sebesar 0.336, menurut katergori Guilford hubungan perencanaan anggaran dan akuntabilitas publik dinilai sedang, pengaruh perencanaan anggaran terhadap akuntabilitas publik sebesar 13.4\%. Masih ada 86.6\% atau pengaruh variabel lainnya (epsilon) diluar pengaruh X1 yang tidak diteliti.

\section{Pengaruh Pengendalian Intern Terhadap Akuntabilitas Publik}

Dari hasil pengujian hipotesis yang dilakukan pada penelitian ini, menunjukkan bahwa menunjukkan bahwa terdapat pengaruh signifikan antara pengendalian intern terhadap akuntabilitas publik (Y). Artinya bahwa setiap peningkatan pengendalian intern akan meningkatkan akuntabilitas publik. Hal tersebut berdasarkan hasil uji statistik diperoleh niali t hitung lebih besar dari nilai t table $6.281>1.694$ sehingga H0 ditolak dan $\mathrm{H} 1$ diterima.

Tabel 4

Koefisien Korelasi dan Determinasi Pengaruh X2 Terhadap Y

Model Summary

\begin{tabular}{|c|c|c|c|c|}
\hline Model & $\mathrm{R}$ & $\mathrm{R}$ Square & $\begin{array}{c}\text { Adjusted } \mathrm{R} \\
\text { Square }\end{array}$ & $\begin{array}{c}\text { Std. Error of the } \\
\text { Estimate }\end{array}$ \\
\hline 1 &, $849^{\mathrm{a}}$ &, 721 &, 712 & 1,152 \\
\hline
\end{tabular}

Berdasarkan hasil olah data pada tabel 04 diketahui nilai koefesien korelasi sebesar 0.849, menurut katergori Guilford hubungan Pengendalian Intern dan akuntabilitas publik dinilai sedang, pengaruh perencanaan anggaran terhadap akuntabilitas publik sebesar 72.1\%. Masih ada 27.9\% atau pengaruh variabel lainnya (epsilon) diluar pengaruh pengendalian intern yang tidak diteliti.

\section{Pengaruh Perencanaan Anggaran dan Pengendalian Intern Terhadap Akuntabilitas Publik}

Dari hasil pengujian hipotesis yang dilakukan dalam penelitian ini, menunjukkan bahwa perencanaan anggaran dan pengendalian intern berpengaruh signifikan terhadap akuntabilitas publik. Hal tersebut berdasarkan hasil uji statistik diperoleh niali F hitung lebih besar dari nilai F tabel $(25,208$ > 3.29) sehingga H0 ditolak dan H1 diterima. Dapat disimpulkan bahwa semakin baik perencanaan anggaran(X1) dan pengendalian intern (X2) maka akan semakin baik pula akuntabilitas publik (Y). 
Tabel 5

Koefisien Korelasi dan Determinasi Pengaruh X1 dan X2 Terhadap Y

Model Summary

\begin{tabular}{|c|c|c|c|}
\hline Model & $\mathbf{R}$ & $\mathbf{R}$ Square & Durbin-Watson \\
\hline 1 &, $797^{\mathrm{a}}$ & 0,635 & 1,858 \\
\hline
\end{tabular}

Berdasarkan hasil olah data pada tabel di atas nilai koefesien korelasi diatas sebesar 0.797 menurut katergori Guilford hubungan perencanaan anggaran dan akuntabilitas publik dinilai sedang. Pengaruh perencanaan anggaran dan pengendalian intern terhadap akuntabilitas publik sebesar $63.5 \%$. Masih ada $36.5 \%$ atau pengaruh variabel lainnya (epsilon) diluar pengaruh X1 yang tidak diteliti.

Perencanaan anggaran dan pengendalian intern mempunyai pengaruh yang positif terhadap akuntabilitas publik, hal ini menandakan ada kecenderungan bahwa perencanaan anggaran dan pengendalian yang lebih baik secara bersamaan mampu mendorong pelaksanaan akuntabilitas secara baik. Pengaruh positif dari perencanaan anggaran dan pengendalian intern terhadap implementasi akuntabilitas publik, menunjukkan bahwa baiknya perencanaan anggaran dan pengendalian intern merupakan determinan akuntabilitas publik. Pelaksanaan pengendalian internal sebagai pemantau dan penilai dalam pelaksanaan anggaran berbasis kinerja dan merupakan salah satu cara mewujudkan akuntabilitas publik.

Akuntabilitas publik sebagai tujuan utama dalam meningkatkan new public management di pemerintahan dinilai kategori baik, hal tersebut menandakan bahwa akuntabilitas publik di Provinsi Riau belum maksimal dilakukan. Akuntabilitas publik dalam penelitian ini terdapat empat pengukuran akuntabilitas public yaitu akuntabilitas kejujuran dan hukum, akuntabilitas proses, akuntabilitas Program dan Akuntabilitas kebijakan yang dijadikan sebagai dimensi akuntabilitas publik.

\section{Perbandingan dengan Peneliti Terdahulu}

Andyrwanto (2016), memperoleh hasil penelitian yaitu Perencanaan anggaran tidak berpengaruh terhadap akuntabilitas publik dan pengendalian intern mempunyai pengaruh yang signifikan terhadap akuntabilitas publik. Sedangkan hasil dari penelitian ini yaitu perencanaan anggaran dan pengendalian intern berpengaruh signifikan terhadap akuntabilitas publik. Jadi hasil dari penelitian ini tidak sejalan dengan peneliti terdahulu karena jumlah sampel yang digunakan berbeda.

Menurut Rakhmini juwita (2016), Hasil dari penelitian yang telah dilakukan yaitu Perencanaan anggaran dan pengendalian intern berpengaruh signifikan terhadap akuntabilitas publik. Sedangkan Hasil dari Penelitian ini yaitu perencanaan anggaran dan pengendalian intern berpengaruh signifikan terhadap akuntabilitas publik. Jadi hasil dari penelitian ini sejalan dengan peneliti terdahulu.

\section{Simpulan dan Saran}

Berdasarkan pembahasan hasil penelitian pengaruh perencanaan anggaran dan pengendalian intern terhadap akuntabilitas publik di Provinsi Riau maka dapat disimpulkan sebagai berikut:

a) Perencanaan anggaran mempunyai pengaruh signifikan terhadap akuntabilitas publik di Provinsi Riau. Hal ini berarti ada kecenderungan bahwa perencanaan anggaran yang lebih baik mampu meningkatkan akuntabilitas publik yang lebih baik. pengaruh perencanaan anggaran terhadap akuntabilitas publik sebesar 13.4\%. Masih ada 86.6\% atau pengaruh variabel lainnya (epsilon) diluar pengaruh X1 yang tidak diteliti. 
b) Pengendalian intern mempunyai pengaruh signifikan terhadap akuntabilitas publik di Provinsi Riau. Hal ini berarti ada kecenderungan bahwa pengendalian intern yang lebih baik mampu meningkatkan akuntabilitas publik yang lebih baik. pengaruh perencanaan anggaran terhadap akuntabilitas publik sebesar $72.1 \%$. Masih ada $27.9 \%$ atau pengaruh variabel lainnya (epsilon) diluar pengaruh pengendalian intern yang tidak diteliti.

c) Perencanaan anggaran dan pengendalian intern mempunyai pengaruh signifikan terhadap akuntabilitas publik di Provinsi Riau. Hal ini berarti ada kecenderungan bahwa perencanaan anggaran dan pengendalian intern yang lebih baik mampu meningkatkan akuntabilitas publik yang lebih baik. Pengaruh perencanaan anggaran dan pengendalian intern terhadap akuntabilitas public sebesar $63,5 \%$, sisanya $36,5 \%$ dipengaruhi oleh faktor lain selain pengendalian intern.

d) Penelitian ini diharapkan dapat bermanfaat bagi peneliti selanjutnya yang akan meneliti dan tertarik dengan judul ini ataupun ada variabel yang mungkin sama, diharapkan untuk lebih mengembangkan variabel perencanaan anggaran, pengendalian intern dan akuntabilitaas publik. Selain itu, penelitian ini diharapkan dapat bermanfaat bagi Pemerintah Daerah Provinsi Riau sebagai pedoman peningkatan kualitas perencanaan anggaran, pengendalian intern dan akuntabilitas publik.

\section{Referensi}

Andirwanto. 2016. Pengaruh perencanaan anggaran dan pengendalian intern terhadap akuntabilitas keuangan daerah dengan realisasi anggaran sebagai variabel intervening (studi skpd kabupaten kepulauan selayar).

Asikin, Decky Firmansyah. 2014. Faktor-Faktor Yang Memengaruhi Penyusunan Anggaran Berbasis Kinerja (Studi Empiris Pada Pemerintah Kota Makassar Provinsi Sulawesi Selatan). Skripsi. Universitas Hasanuddin Makassar.

Bastian, I. 2010. Akuntansi Sektor Publik Suatu Pengantar Edisi Ketiga. Erlangga. Jakarta.

Fatmala, Juanita. 2014. Pengaruh Penerapan Sistem Akuntansi Pemerintah Daerah, Pemahaman Akuntansi, dan Ketaatan Pada Peraturan Perundangan Terhadap Akuntabilitas Kinerja Instansi Pemerintah. Skripsi. Universitas Bengkulu.

Hehanussa, Salomi j. 2015. Pengaruh Penyajian Laporan Keuangan Daerah dan Aksesibilitas Laporan Keuangan Daerah Terhadap Transparansi dan Akuntabilitas Pengelolaan Keuangan Daerah. Skripsi. Sultan Agung Islamic University.

Indriantoro, Nur dan Bambang Supomo. 2014. Metodelogi penelitian bisnis. Yogyakarta : BPFE.

Mardiasmo. 2009. “Akuntansi Sektor Publik", Cetakan ke empat, Penerbit Andi, Yogyakarta. 
Muhanafiah, Rizal Fadilah. 2015. Pengaruh Efektivitas Sistem Pengendalian Internal Pemerintah Terhadap Kualitas Laporan Realisasi Anggaran. Skripsi. Universitas Widyatama.

Republik Indonesia, Peraturan Pemerintah No. 58 Tahun 2005 Tentang Pengelolaan Keuangan Daerah.

Republik Indonesia, Keputusan Menteri Dalam Negeri No. 60 Tahun 2008 tentang Sistem Pengendalian Intern Pemerintah.

Saleba, Sitti Nurjannah. 2014. Pengaruh Sistem Pengendalian Intern Pemerintah dan Kompetensi Sumber Daya Manusia Terhadap Efektivitas Pengelolaan Keuangan Daerah. Skripsi. Universitas Hasanuddin Makassar.

Sudaryanti, Dwi. 2013. Pengaruh Penganggaran Terhadap Kinerja Aparat Pemda Melalui Sistem Informasi Keuangan Daerah (Studi Kasus: Pemda Kab Kudus). Jurnal Ekonomi Dan Bisnis. Volume 12. Nomor 01.

Sugiharto. 2013. Pengaruh Kualitas Anggaran dan Pengendalian Anggaran Terhadap Efektivitas Organisasi di Lingkungan Pemerintahan Kota Jambi. Alumni Magister Ilmu Akuntansi. Universitas Jambi. Sujarweni, V. Wiratna. 2014. SPSS untuk Penelitian. Yogyakarta : Pustaka Baru Press.

Wicaksono, Widi Cahyo. 2013. Faktor-Faktor Yang Mempengaruhi Efektivitas Pengendalian Intern di Sektor Pemerintahan (Persepsi Pegawai Pada DinasDinas Kota Semarang. Skripsi. Universitas Negeri Semara. 